\title{
A new spiny species of Hypostomus Lacépède (Loricariidae: Hypostominae) from thermal waters, upper rio Paraná basin, central Brazil
}

\author{
Fernanda O. Martins ${ }^{1}$, Francisco Langeani ${ }^{1}$ and Cláudio H. Zawadzki²
}

A new species of Hypostomus is described from the rio Quente, rio Paranaíba drainage, in the upper rio Paraná basin in central Brazil. The rio Quente is a peculiar small and shallow fast water stream with water temperatures around $34^{\circ} \mathrm{C}$. The new species is distinguished from all congeners by having the five lateral series of plates with hypertrophied odontodes not aligned in rows and more conspicuous on flanks of caudal peduncle of the larger specimens. The new species is only known from the rio Quente.

Uma nova espécie de Hypostomus é descrita do rio Quente, drenagem do rio Paranaíba, bacia do alto rio Paraná no Brasil Central. O rio Quente é um riacho peculiar, raso e de correnteza, cujas temperaturas atingem em torno de $34^{\circ} \mathrm{C}$. A espécie nova é distinguida de todas as congêneres por ter as cinco séries de placas laterais com odontódeos hipertrofiados, os quais não são alinhados em fileiras, sendo mais conspícuos nos flancos do pedúnculo caudal nos indivíduos maiores. A espécie nova é conhecida apenas do rio Quente.

Key words: Freshwater fishes, Neotropical region, Rio Quente, Siluriformes, Taxonomy.

\section{Introduction}

The genus Hypostomus Lacépède bears the greatest diversity within the Loricariidae, with about 130 valid species (Eschmeyer, 2012; Zawadzki et al., 2014). The phylogenetic relationships among these species are still unclear and the monophyly of the genus is subject of many morphological and molecular studies (e.g., Montoya-Burgos, 2003; Armbruster, 2004). The rio Paraná basin shelters more than 30 of these species, most of them described in the early twentieth century which renders taxonomic questions such as H. fluviatilis (Schubart), H. meleagris (Marini, Nichols \& La Monte), H. scaphiceps (Nichols), and H. topavae (Godoy).

The upper rio Paraná basin is a well-sampled ecoregion (sensu Abell et al., 2008) and has one of the better known ichthyofaunas in Brazil (Langeani et al., 2007). However, some of its unexplored areas still reserve undiscovered taxa, mainly on its headwaters. The rio Quente, a tributary of the rio Piracanjuba, rio Paranaíba drainage, upper rio Paraná basin, located in the southern Goiás State, central Brazil, can be considered one of these underexplored areas. This is a natural stream of warm water that starts to flow at $700 \mathrm{~m}$ above sea level, in the upper part of the western flank of the Caldas Novas dome. The springs of thermal waters rise to the surface at temperatures around $50^{\circ} \mathrm{C}$ from a series of open spaces in the basal layers of quartzite of the Paranoá Group, and remain relatively warm downstream (D'el-Rey Silva et al., 2008). According to these authors, the rio Quente is unique, and there is no other natural spring of thermal waters in the region.

Recent samples in the rio Quente revealed the presence of a peculiar spiny species of Hypostomus which does not pertain to any of the known species for the genus and is herein described.

${ }^{1}$ UNESP, Universidade Estadual Paulista “Júlio de Mesquita Filho", Instituto de Biociências, Letras e Ciências Exatas, Departamento de Zoologia e Botânica, Laboratório de Ictiologia. Rua Cristóvão Colombo, 2265, 15054-000 São José do Rio Preto, SP, Brazil. fernanda_martins2@hotmail.com; langeani@ibilce.unesp.br

${ }^{2}$ UEM, Universidade Estadual de Maringá, Departamento de Biologia e Nupélia, Núcleo de Pesquisas em Limnologia, Ictiologia e Aquicultura. Av. Colombo, 5790, 87020-900 Maringá-PR, Brazil. chzawadzki@hotmail.com 


\section{Material and Methods}

Measurements and counts were taken according to Boeseman (1968) and Weber (1985). All measurements were taken point to point with digital calipers to the nearest $0.1 \mathrm{~mm}$. Body measurements are given as percents of the standard length (SL), except when noted; subunits of the head are given as percents of head length (HL). Vertebrae count included the five vertebrae from the Weberian apparatus, and the compound caudal centrum was counted as a single element. Body plate nomenclature was based on Schaefer (1997) with modifications by Oyakawa et al. (2005). In the description, the mode of each count is given in parentheses after the respective count. Specimens were cleared and stained (c\&s) according to Taylor \& Van Dyke (1985).

Institutional abbreviations are: AMNH, American Museum of Natural History, New York; ANSP, Academy of Natural Sciences of Drexel University, Philadelphia; BMNH, Natural History Museum, London; DZSJRP, Coleção de Peixes do Departamento de Zoologia e Botânica do Instituto de Biociências, Letras e Ciências Exatas, Universidade Estadual Paulista, São José do Rio Preto; MCP, Museu de Ciências e Tecnologia, Pontifícia Universidade Católica do Rio Grande do Sul, Porto Alegre; MHNG, Muséum d'histoire naturelle - Ville de Genève, Geneva; MNHN, Muséum national d'histoire naturelle, Paris; MNRJ, Museu Nacional, Universidade Federal do Rio de Janeiro, Rio de Janeiro; MZUSP, Museu de Zoologia, Universidade de São Paulo, São Paulo; NUP, Coleção Ictiológica do Núcleo de Pesquisas em Limnologia, Ictiologia e Aquicultura, Universidade Estadual de Maringá, Maringá.

\section{Results \\ Hypostomus yaku, new species \\ Figs. 1-3}

Holotype. DZSJRP 15735, 70.8 mm SL, Brazil, Goiás State, município de Rio Quente, upper rio Paraná basin, rio Paranaíba drainage, tributary of rio Piracanjuba, rio Quente basin, near water treatment station, $17^{\circ} 46^{\prime} 32^{\prime \prime} \mathrm{S} 48^{\circ} 45^{\prime} 56^{\prime \prime} \mathrm{W}$, 618 m a.s.l., 7 Mar 2012, F. Langeani, F. R. Carvalho \& F. O. Martins.

Paratypes. All from Brazil, Goiás State, município de Rio Quente, upper rio Paraná basin, rio Quente, tributary of rio Piracanjuba, rio Paranaíba drainage. AMNH 258952, 3, 30.2$45.6 \mathrm{~mm}$ SL, DZSJRP 16421, 72, 10.7-60.7 mm SL, MCP 48101, 3, 29.6-48.5 mm SL (48.5 mm SL), MNRJ 41722, 3, 28.3-50.2 mm SL (50.2 mm SL), MZUSP 115072, 3, 24.0$53.5 \mathrm{~mm}$ SL (44.7-53.5 mm SL), NUP 15348, 6, 29.8-58.1 $\mathrm{mm}$ SL (41.3-58.1 mm SL), all collected with holotype. DZSJRP 15743, 3, 30.2-48.7 mm SL, rio Quente near the bridge, at Rio Quente Resort, in the road to Pousada Hotel, $17^{\circ} 46^{\prime} 28^{\prime \prime} \mathrm{S} 48^{\circ} 45^{\prime} 13^{\prime \prime} \mathrm{W}, 596 \mathrm{~m}$ above sea level, $8 \mathrm{Mar}$ 2012, F. Langeani, F. R. Carvalho, F. O. Martins. DZSJRP 15747, 12, 12.4-59.7 mm SL (42.3-59.7 mm SL), rio Quente, under the bridge at Esplanada district, $17^{\circ} 46^{\prime} 22^{\prime \prime} 48^{\circ} 45^{\prime} 23^{\prime \prime}$, 622 m a.s.l., 8 Mar 2012, F. Langeani, F. R. Carvalho, F. O. Martins.

Diagnosis. The new species is distinguished from all congeners by having the five lateral series of plates with hypertrophied odontodes, not aligned in longitudinal rows, more conspicuous on flanks of caudal peduncle of the larger specimens ( $v s$. lateral series of plates lacking hypertrophied odontodes or with aligned hypertrophied odontodes only along the longitudinal keels) (Fig. 2).

Description. Morphometric and meristic data in Table 1. Largest specimen examined $70.8 \mathrm{~mm}$ SL. Body deepest at dorsal-fin origin. Dorsal profile of body in lateral view ascendant from tip of snout to nares; convex from nares to dorsal-fin origin; slightly descending to caudal-fin base. Ventral profile of body in lateral view almost straight from tip of snout to pelvic-fin origin; posterodorsally inclined from pelvic-fin origin to caudal-fin base. Caudal peduncle ovoid in cross-section. Anterior profile of snout markedly rounded in dorsal view.

Posterior process of supraoccipital bordered by one or two predorsal plates. Opercle rectangular, with 40-70 small to well-developed odontodes, mainly in ventral margin. Preopercle without odontodes, partially covered by four platelets. Preopercle branch of laterosensory system entering from suprapreopercle, passing through preopercle, and reaching small single canal-bearing plate (cp1). Three cheek plates with large and strong odontodes between opercle and canal-bearing plate; cheek plates not evertible. Eye small, 2.0-2.5 times in interorbital width, dorsolaterally placed; iris operculum present, well developed; space between orbits concave. Nares separated by flap of skin. Oral disk elliptical, wider than long and papillose. Papillae at upper lip ovoid and larger, rounded and smaller at lower lip, decreasing in size towards margins in both lips. Outer margin of upper lip with small lateral isolated patch with few odontodes. Lower lip with fringed margin, not reaching transverse line through gill openings and scapular bridge. Maxillary barbel shorter than orbital diameter, proximally linked to lip, ornamented with small papillae. Angle between contralateral dentaries approximatelly $170^{\circ}$. Premaxillary teeth 27 to 69 (43); dentary teeth 31 to 72 (49). Teeth bicuspid; newly emerged ones with medial cusp well developed, considerably larger than lateral cusp; most teeth in functional series with subequal cusps, some with symmetrical cusps (Fig. 3).

Tip of snout dorsally covered by small plates and odontodes, anteroventral portion completely naked, except for two lateral patches of very small plates with odontodes. Odontodes in most anterior portion of snout markedly rounded. Ventral surface of head naked; sometimes few odontodes near opercular opening. Five complete lateral series of plates. Dorsal plate series with six to seven (seven) plates delimiting a naked area along dorsal-fin base. Median series with 23-25 (24) perforated plates. Ventral plate series 
starting at vertical through pelvic-fin origin, with two to three ventral plates along anal-fin base, and 11 to 13 ventral plates from end of anal-fin base to caudal-fin origin. Lateral series of plates with poorly-developed longitudinal keels: from dorsal-fin origin to end of caudal peduncle on dorsal series; from compound pterotic to end of caudal peduncle on mid-dorsal and median series, and to vertical through second or third branched dorsal-fin ray on mid-ventral series; keels absent on ventral series. Lateral plates covered by irregularly arranged odontodes; each plate with two to four hypertrophied straight odontodes posteriorly oriented, more conspicuous on flanks at posterior portion of caudal peduncle (Fig. 2); odontodes with tips slightly curved laterally in larger specimens. Abdomen naked, except for lateral platelets between pectoral- and pelvic-fin origins, and at pectoral girdle region; platelets absent in juveniles.

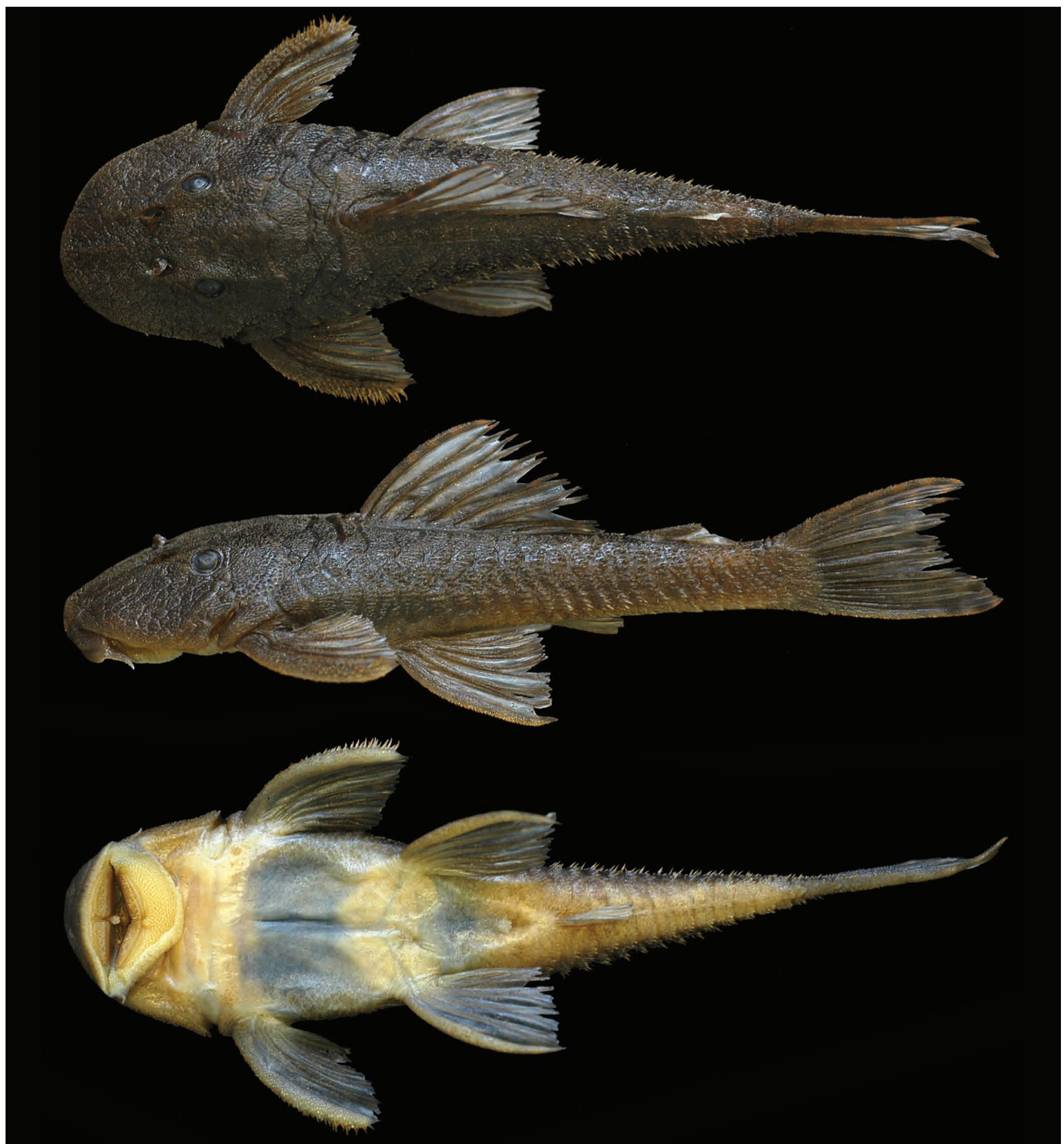

Fig. 1. Hypostomus yaku, holotype, DZSJRP 15735, $70.8 \mathrm{~mm} \mathrm{SL}$, rio Quente, rio Paranaíba drainage, upper rio Paraná basin, Rio Quente, Goiás State, Brazil. 


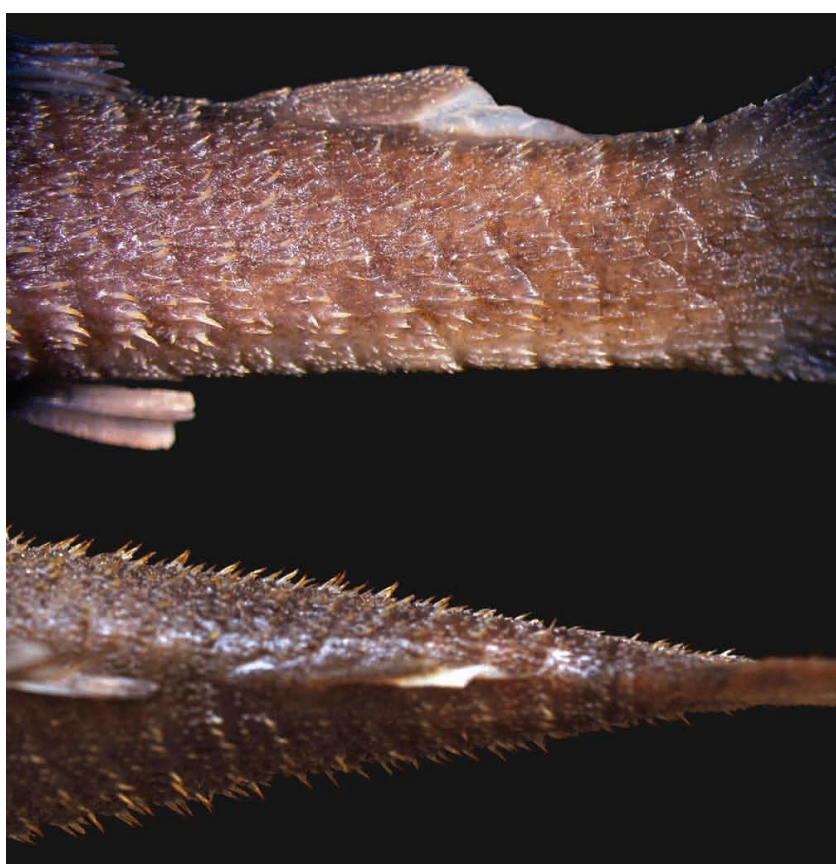

Fig. 2. Detail of the hypertrophied odontodes on the lateral plates of the posterior portion of caudal peduncle in dorsal and lateral views, DZSJRP 15735, holotype, $70.8 \mathrm{~mm}$ SL.
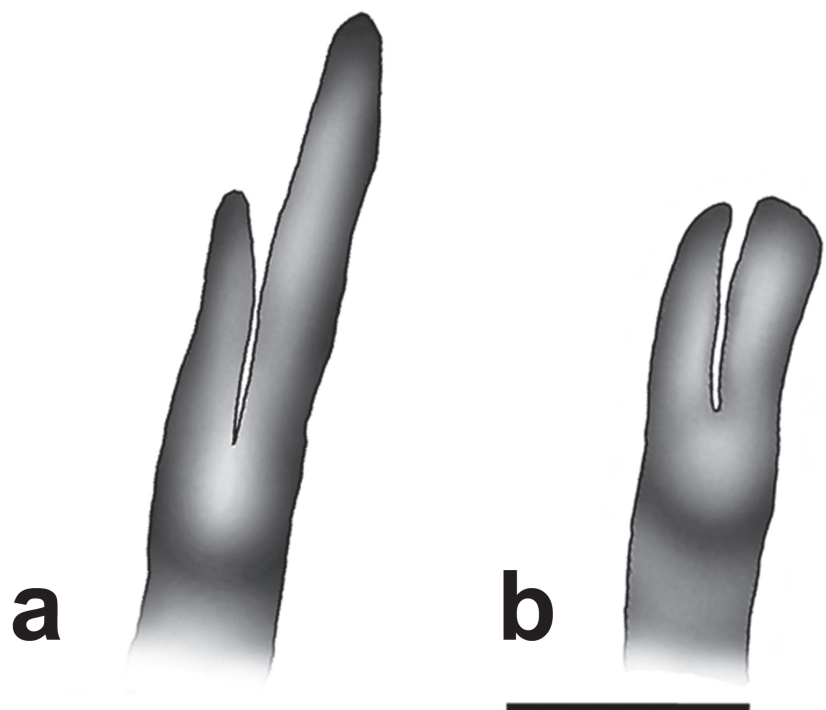

Fig. 3. Dentary teeth from the same specimen of Hypostomus yaku, paratype, DZSJRP 16421, $60.5 \mathrm{~mm} \mathrm{SL}$, showing the different size of the medial cuspid according to time of emergence. a) new emerging tooth; b) worn tooth. Scale bar $=0.05 \mathrm{~mm}$.

Dorsal fin with seven branched rays, posterior border convex; tip of adpressed rays extending almost to vertical through end of last anal-fin ray, not reaching adipose-fin spine; well-developed V-shaped spinelet present, locking mechanism functional; tip of first and last proximal radials contacting neural spine of seventh and $15^{\text {th }}$ or $16^{\text {th }}$ vertebrae, respectively. Adipose fin triangle-shaped; distal border not free from caudal peduncle surface, extending in oblique descendent line (Fig. 2); adipose-fin spine markedly straight; one or two pre-adipose azygous plates. Pectoral fin with six branched rays; spine strong and distally covered with welldeveloped odontodes; tip of adpressed pectoral-fin rays reaching posteriormost portion of pelvic-fin base. Cleithrum exposed projection truncated posteriorly. Pelvic fin with thin and flexible spine, and five branched rays; tip of adpressed pelvic fin surpassing end of anal-fin base. Anal fin with thin and flexible unbranched ray, and four branched rays; first proximal radial not exposed ventrally; tip of first and last proximal radials contacting hemal spine of $14^{\text {th }}$ and $18^{\text {th }}$ vertebrae, respectively. Caudal fin concave, with two outer unbranched rays and 14 or 15 (one specimen) inner branched rays; lower lobe longer than upper one; four to five dorsal and two to four ventral procurrent rays. Vertebrae 27-28.

Color in alcohol. Ground color of dorsal and lateral surfaces homogeneously brown in head and trunk; ventral surface light brown, lighter along head. Some specimens with slightly darker chromatophores forming dots on head, smaller than eye diameter, and four inconspicuous dorsal dark brown saddles on trunk: two anteriormost along dorsal-fin base; third along adipose fin and slightly ahead; fourth shorter at end of caudal peduncle. All fins with hyaline membranes and medium to dark brown rays forming inconspicuous transverse bars.

Distribution. Hypostomus yaku is known from the rio Quente, a small tributary of rio Piracanjuba, rio Paranaíba drainage, upper rio Paraná basin, central Brazil (Fig. 4).

Ecological notes. Specimens were sampled in warm water, with temperature around $34^{\circ} \mathrm{C}$. The type locality, where specimens were more abundant, is about three meters wide and 1.0-1.5 m deep, with moderate flow and bottom with sand, pebbles and rocks; specimens of $H$. yaku were associated predominantly with the rocks. Other species collected with Hypostomus yaku are: Characidium xanthopterum Silveira, Langeani, da Graça, Pavanelli \& Buckup, Characidium aff. zebra, Knodus moenkhausii (Eigenmann \& Kennedy), an undescribed species of a putatively new genus of the Characidae, and the exotic Xiphophorus helleri Heckel and Oreochromis niloticus (Linnaeus). The low species richness may be related to water temperature, since life in thermal water demands some physiological specializations.

Hypostomus yaku seems to be restricted to warm waters, such as areas inside the Rio Quente Resort and other sites in the urban area of the Municipality of rio Quente. Samples made in other nearby streams with lower water temperature did not yield specimens of the species. Although very abundant in the type locality, this restricted occurrence to areas with anthropic influence (e.g., urban expansion, tourism, organic pollution) requires special attention to the conservation of Hypostomus yaku, with frequent monitoring of the populations of the species. 
Table 1. Morphometric and meristic data of the holotype and 29 paratypes of Hypostomus yaku. Means are presented for measurements, and modes for counts. The range includes the holotype. SD = Standard deviation.

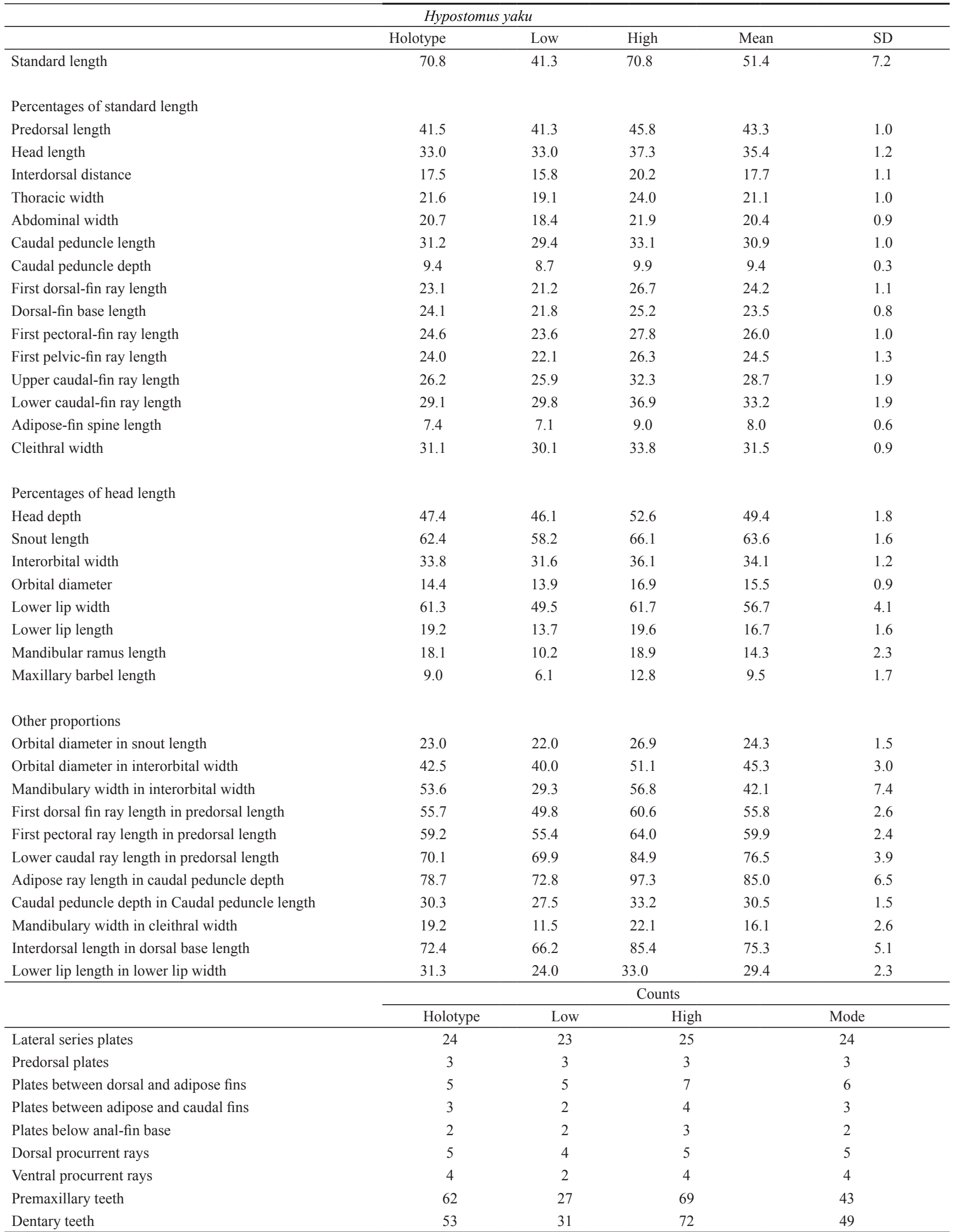




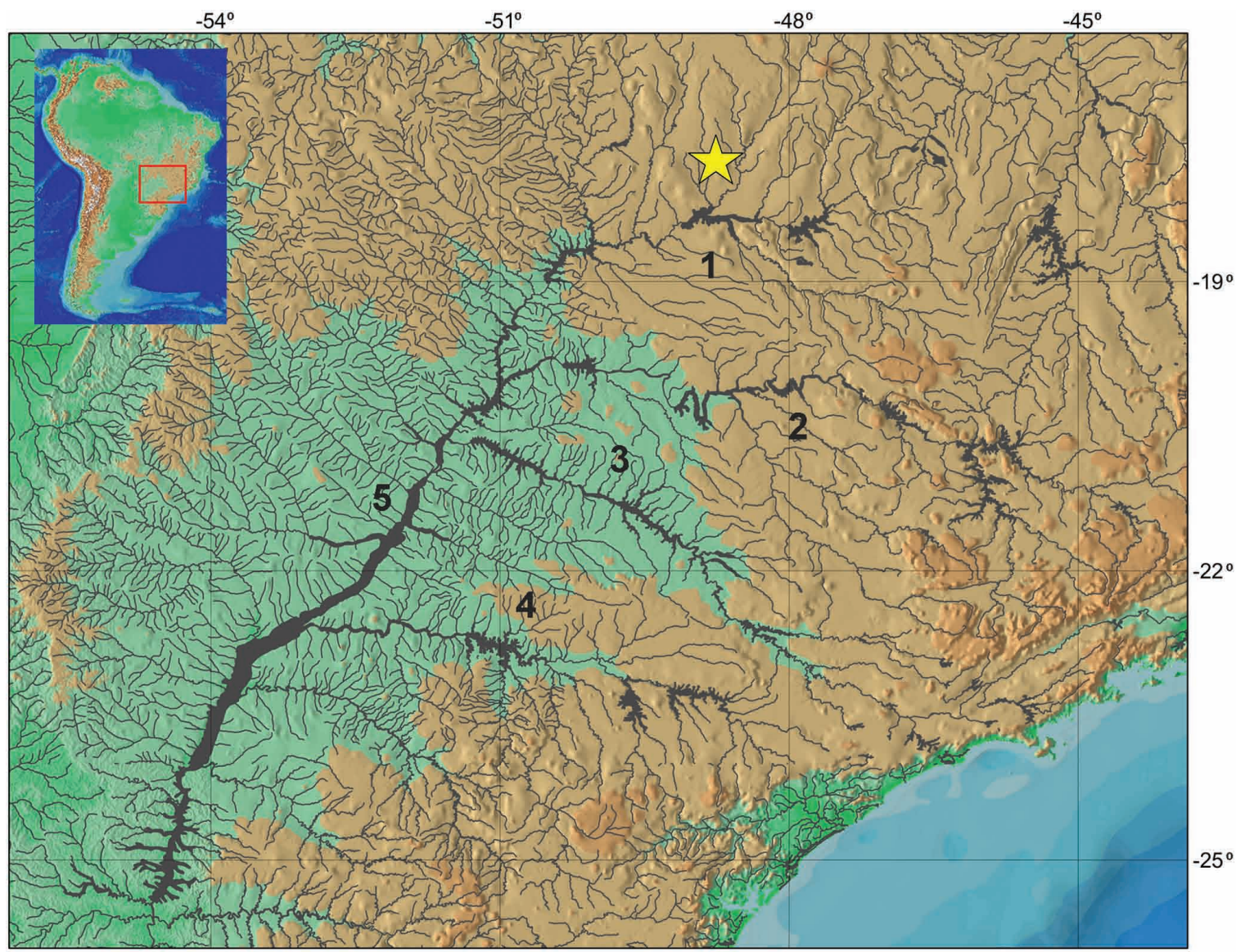

Fig. 4. Map of southeastern Brazil showing type locality of Hypostomus yaku, rio Quente, tributary of rio Piracanjuba, rio Paranaíba drainage, upper rio Paraná basin (1 - rio Paranaíba; 2 - rio Grande; 3 - rio Tietê; 4 - rio Paranapanema; 5 - rio Paraná).

Etymology. In the specific name $y a k u$, from the Tupi Guarani language, dialect Mbyá, $y$ means water, and raku means hot, warm, a reference to the name of the rio Quente, a warm water river. A noun in apposition.

\section{Discussion}

Hypertrophied odontodes on flanks in the Hypostominae are mainly found in species of Aphanotorulus Isbrücker \& Nijssen, Peckoltia Miranda Ribeiro [as in some specimens of $P$. brevis (La monte)], Squaliforma Isbrücker \& Michels, and even in some keeled species of Hypostomus. However, Hypostomus yaku is clearly distinct from these genera by lacking conspicuous hypertrophied cheek odontodes on evertible plates of preopercular region $[v s$. presence in Peckoltia, as suggested by Armbruster (2008)]; and by lacking numerous hypertrophied papillae into the mouth, and by having the caudal peduncle ovoid in cross-section ( $v S$. presence of hypertrophied papillae into the mouth and contour area of caudal peduncle trapezoid due to a strong angle along the mid-ventral series of plate in Aphanotorulus and Squaliforma). Among Hypostomus species, hypertrophied odontodes on flanks are also observed in $H$. carinatus Kner, $H$. commersoni Valenciennes, $H$. delimai Zawadzki, de Oliveira \& Debona, and H. hoplonites Rapp Py-Daniel. However, these odontodes are relatively smaller and longitudinally aligned on the keels along the lateral series of plates, instead of larger odontodes randomly distributed on the flank, neither aligned nor restricted to the longitudinal keels, as found in Hypostomus yaku.

Hypostomus yaku is morphologically more similar to two widespread species inhabiting small, fast flowing waters and rocky streams in the upper rio Paraná basin: H. nigromaculatus (Schubart) and $H$. paulinus (Ihering). Hypostomus nigromaculatus is a small-sized species, with larger mature males usually reaching around $90.0 \mathrm{~mm}$ SL (NUP 10744), and differs from $H$. yaku by having conspicuous dark spots, increasing in size backwards, deeper head, and short, curved pectoral-fin spine usually enlarged on distal region, having a club-shaped aspect. Hypostomus paulinus is the most similar species to H. yaku. Nogueira et al. (2010) have cited it as a restricted-range species, however $H$. paulinus can be found in most rocky headwater tributaries of the upper rio Paraná with shallow and fast flowing waters. Although being considered as a small species, mature specimens of $H$. paulinus from the rio Piracicaba, its type locality, can reach up to $135.0 \mathrm{~mm}$ SL (holotype, BMNH 1905.6.9.4); this is twice the size and considerably longer than the largest specimen (holotype) of the new species. Differing from $H$. yaku, hypertrophied odontodes are lacking even in the largest specimens of $H$. 
paulinus. Hypotomus yaku also has smaller eyes, 13.9-16.9\% in HL than $H$. paulinus from the rio Piracicaba basin (17.5$22.1 \%$ in HL, mean $19.5 ; n=23$; C. H. Zawadzki, pers. obs.). Furthermore, Hypostomus nigromaculatus and $H$. paulinus also differ from $H$. yaku in having the posterior border of the adipose-fin membrane vertical and straight or slightly convex (vs. forming an oblique descendent line in H. yaku).

The most plausible hypothesis is that $H$. yaku is very closely related to $H$. paulinus since both species share many features such as: small to medium size; body relatively depressed to a Hypostomus species; pectoral spine somewhat curved and bearing hypertrophied odontodes; straight and back oriented adipose fin; and plates on the abdomen ontogenetically appearing from cleithral and lateral regions of the abdomen to its center. In fact, a revision of several populations of $\mathrm{H}$. paulinus is in progress by $\mathrm{CHZ}$ and more new species could be revealed under the current name of Hypostomus paulinus.

Zawadzki et al. (2008b) recently described two new species of Hypostomus from the rio Paranaíba basin, $H$. denticulatus and $H$. heraldoi. Hypostomus denticulatus was distinguished by having symmetrical bicuspid teeth and $H$. heraldo $i$ by having the unbranched pectoral-fin ray equal to or larger than the unbranched pelvic-fin ray. Recently, the rio Paranaíba basin was a source of several other new species of loricariids such as the neoplecostomine Neoplecostomus corumba Zawadzki, Pavanelli \& Langeani, a new genus of hypoptopomatine, Rhinolekos, with three species, $R$. britskii Martins, Langeani \& Costa, $R$. garavelloi Martins \& Langeani, and R. schaeferi Martins \& Langeani, and also Microlepidogaster arachas Martins, Calegari \& Langeani, Microlepidogaster longicolla Calegari \& Reis and Hisonotus piracanjuba Martins \& Langeani (Zawadzki et al., 2008a; Martins \& Langeani, 2011; Martins et al., 2013; Calegari \& Reis, 2010; Martins \& Langeani, 2012, respectively).

The headwaters of the main right tributaries of the rio Paranaíba, such as the rios Correntes, São Marcos, Corumbá, and Meia Ponte are nested in the southern border of the Brazilian central shield and run southward to the Paranean Plateau. These tributaries drain some uplifted regions (Serra dos Pirineus, Serra dos Cristais, Morro dos Padres) with altitudes from 1200 to $800 \mathrm{~m}$ a.s.l. to southern plateaus from 800 to $500 \mathrm{~m}$ a.s.l., through valleys and depressions to reach the rio Paranaíba (Nascimento, 1992). The environmental heterogeneity of the several pristine fast waters and rocky streams bears conditions to small and medium fishes as some of these loricariid to be isolated and hence fix the distinctive characters of these species. Therefore, some more new species are expected to be revealed from the region as more groups of fish are better studied.

Comparative material examined. Hypostomus albopunctatus: Brazil, Paraná State, upper rio Paraná basin, NUP 12378, 1, 207.0 mm SL, ribeirão Atlântico, tributary of rio Pirapó; NUP 15147, 7, 92.1-117.4 mm SL, rio São Francisco Verdadeiro, tributary of rio Paraná. São Paulo State, upper rio Paraná basin, BMNH 1907.7.6.15,
2, 134.1-169.0 mm SL, syntypes, rio Piracicaba; MZUSP 87176, 2, 120.5-154.8 mm SL, rio Jacaré-Guaçu. Hypostomus ancistroides: Brazil, São Paulo State, upper rio Paraná basin, MZUSP 2131, 4, 95.6-165.1 mm SL, rio Tatuí; NUP 15205, 7, 121.9-153.4 mm SL, córrego das Pedras, tributary of rio Paranapanema; NUP 15232, 2, 69.9-98.1 mm SL, rio Capivara, rio Tietê drainage. Hypostomus borellii: Bolivia, rio Paraguay basin, BMNH 1897.1.27.19, 1, 153.1 mm SL, syntype, río Pilcomayo. Hypostomus boulengeri: Brazil, Mato Grosso State, rio Paraguay basin, NUP 414, 3, 165.8-175.6 $\mathrm{mm}$ SL, rio Manso; NUP 1078, 2, 210.0-220.0 mm SL, rio Manso Reservoir; NUP 3273, 8, 110.0-166.0 mm SL, rio Manso; NUP 8692, 1, 190.0 mm SL, rio Quilombo; NUP 8695, 1, 170.0 mm SL, rio Manso. Hypostomus careopinnatus: Brazil, Mato Grosso State, rio Paraguay basin, NUP 11257, 5, 30.2-53.8 mm SL, paratypes, tributary of rio Ariranha. Hypostomus dlouhyi: Paraguay, Alto Paraná Department, río Paraná basin, MHNG 2229.43, 1, 139.5 mm SL, holotype, río Yguazú. Hypostomus laplatae: Argentina, río de La Plata basin, BMNH 1908.8.29.17, 1, 207.3 mm SL, río de La Plata. Hypostomus microstomus: Brazil, Paraná State, upper rio Paraná basin, NUP 15173, 1, 178.3 mm SL, rio Paraná. Paraguay, Itapua Department, rio Paraná basin, MHNG 2367.90, 197.5 mm SL, holotype, río Paraná. Hypostomus multidens: Brazil, Paraná State, upper rio Paraná basin, NUP 6776, 1, 167.0 mm SL, rio Paraná. São Paulo State, upper rio Paraná basin, NUP 5340, paratype, $157.0 \mathrm{~mm}$ SL, rio Paranapanema; Chavantes Reservoir. Hypostomus mutucae: Brazil, Mato Grosso State, rio Paraguay basin, MCP 28669, 67.7 mm SL, holotype, rio Mutuca; NUP 6641, 13, 52.4-109.2 mm SL, rio Claro; NUP 6642, 4, 62.1-98.1 mm SL, rio Claro. Hypostomus nigromaculatus: Brazil, Goiás State, upper rio Paraná basin, NUP 4079, 2, 71.0-76.0 mm SL, rio Pirapitinga, tributary of rio Corumbá. Paraná State, upper rio Paraná basin, NUP 5070, 4, 53.7-68.6 mm SL, ribeirão Três Bocas, tributary of rio Tibagi; NUP 5384, 3, 61.175.8 mm SL, ribeirão Atlântico, tributary of rio Pirapó; NUP 6008, 15, 23.1-74.5 mm SL, córrego Água Queçaba, tributary of rio Pirapó. São Paulo State, upper rio Paraná basin, MZUSP 22674, 9, 43.8-75.9 mm SL, cachoeira de Emas, rio Mogi-Guaçu; NUP 5381, 4, 49.8$75.3 \mathrm{~mm}$ SL, ribeirão Pirapitinga, tributary of rio Piracicaba; NUP 6412, 2, 51.7-67.1 mm SL, rio Piracicaba, tributary of rio Tietê; NUP 10348, 1, $83.4 \mathrm{~mm}$ SL, cachoeira de Emas, rio Mogi-Guaçu, tributary of rio Grande; NUP 10744, 6, 49.2-85.0 mm SL, cachoeira de Emas, rio Mogi-Guaçu, tributary of rio Grande. Hypostomus paranensis: Argentina, Cordoba Department, río Paraná basin, $\mathrm{BMNH}$ 1878.4.4.1, $178.3 \mathrm{~mm}$ SL, holotype of Plecostomus cordovae, río Paraná. Río Paraguay basin, MZUSP 23805, 6, 47.5-111.3 mm SL, río Segundo. Hypostomus paulinus: Brazil, Paraná State, upper rio Paraná basin, NUP 9398, 1, 98.5 mm SL, rio do Campo, tributary of rio Ivaí. São Paulo State, upper rio Paraná basin, NUP 5344, 1, 69.0 mm SL, rio Passa Cinco, tributary of rio Piracicaba; NUP 5379, 2, 84.1-91.7 mm SL, rio Passa Cinco, tributary of rio Piracicaba; NUP 5722, 1, $90.5 \mathrm{~mm}$ SL, rio Passa Cinco, tributary of rio Piracicaba; NUP 6411, 17, 46.5-103.28 mm SL, rio Piracicaba, tributary of rio Tietê; NUP 6413, 13, 45.9-98.9 mm SL, rio Piracicaba, tributary of Tietê; NUP 6894, 2, 74.4-76.0 mm SL, ribeirão Laranja Azeda, tributary of rio Paranapanema. Hypostomus regani: Brazil, Goiás State, upper rio Paraná basin, NUP 14225, 2, 136.9-150.1 mm SL, ribeirão das Antas, tributary of rio Paranaíba. Paraná State, upper 
rio Paraná basin, NUP 5601, 5, 138.4-209.4 mm SL, rio Piquiri. São Paulo State, upper rio Paraná basin, BMNH 1905.6.7.3, 174.2 mm SL, holotype, rio Piracicaba; NUP 6117, 1, $147.0 \mathrm{~mm}$ SL, rio Verde, tributary of rio Paraná. Hypostomus strigaticeps: Brazil, Goiás State, upper rio Paraná basin, NUP 14970, 9, 24.4-89.5 mm SL, córrego Taquaral, tributary of rio Corumbá. São Paulo State, upper rio Paraná basin, BMNH 1907.7.6.1012, syntypes, 3, 75.7-160.0 mm SL, rio Piracicaba, rio Tietê drainage; NUP 4017, 2, 72.8-100.0 mm SL, rio Ipanema, rio Tietê drainage; NUP 4538, 11, 82.0-140 mm SL, rio Corumbataí, tributary of rio Tietê. Hypostomus ternetzi: Brazil, Mato Grosso State, rio Paraguay basin, BMNH 1895.5.17.64, 210.2 mm SL, holotype, rio Paraguay; NUP 1651, 2, 107.5-111.0 mm SL, rio Manso. Paraná State, upper rio Paraná basin, NUP 15198, 7, 112.0-141.2 mm SL, Itaipu Reservoir, rio Paraná. Hypostomus topavae: Brazil, Paraná State, upper rio Paraná basin, NUP 4003, 8, 96.1-124.7 mm SL, rio Pirapó, tributary of rio Paranapanema. São Paulo State, upper rio Paraná basin, NUP 6503, 3, 41.0-61.4 mm SL, rio da Palma, tributary of rio do Peixe; NUP 10623, 1, $106.8 \mathrm{~mm}$ SL, cachoeira de Emas, rio Mogi-Guaçu, tributary of rio Grande; NUP 11980, 14, 29.1-101.4 mm SL, córrego Toledinho, tributary of rio Aguapeí.

\section{Acknowledgments}

We are grateful to Rio Quente Resorts management for allowing the access to the resort area and for guiding us during our visit, and to Fernando Carvalho (DZSJRP) for help in fieldwork. The authors were supported by the Fundação de Amparo à Pesquisa do Estado de São Paulo (FAPESP, \#2011/21728-7 to FOM, \#2004/00545-8 and \#2009/54949-6 to FL), and Conselho Nacional de Desenvolvimento Científico e Tecnológico (CNPq, \#305946/2011-0 to FL and \#310733/2013-8 to CHZ).

\section{Literature Cited}

Abell, R., M. L. Thieme, C. Revenga, M. Bryer, M. Kottelat, N. Bogutskaya, B. Coad, N. Mandrak, S. Contreras-Balderas, W. Bussing, M. L. J. Stiasnny, P. Skelton, G. R. Allen, P. Unmack, A. Naseka, R. Ng, N. Sindorf, J. Robertson, E. Armijo, J. V. Higgins, T. J. Heibel, E. Wikramanayake, D. Olson, H. L. López, R. E. Reis, J. G. Lundberg, M. Sabaj-Pérez \& P. Petry. 2008. Freshwater Ecoregions of the World: biogeographic units for freshwater biodiversity conservation. BioScience, 58: 403-414.

Armbruster, J. W. 2004. Phylogenetic relationships of the suckermouth armoured catfishes (Loricariidae) with emphasis on the Hypostominae and the Ancistrinae. Zoological Journal of the Linnean Society, 141: 1-80.

Armbruster, J. W. 2008. The genus Peckoltia with the description of two new species and a reanalysis of the phylogeny of the genera of the Hypostominae (Siluriformes: Loricariidae). Zootaxa, 1822: 1-76.

Boeseman, M. 1968. The genus Hypostomus Lacépède, 1803, and its Surinam representatives (Siluriformes, Loricariidae). Zoologische Verhandelingen, 99: 1-89.

Calegari,B.B.\&R.E.Reis.2010.Anewspecies of Microlepidogaster (Siluriformes: Loricariidae: Hypoptopomatinae) from the upper rio Paraná basin, Brazil. Neotropical Ichthyology, 8: 625-630.
D’él-Rey Silva, L. J. H., D. H. Walde, J. E. G. Campos \& R. A. Cipullo. 2008. First WSEAS International Conference on environmental and geological science and engineering. Why the Rio Quente is a special spring within the Caldas Novas Thermal Aquifer, central Brazil? Available from http://www.wseas.us/elibrary/conferences/2008/malta/eg/eg07.pdf (27 May 2014).

Eschmeyer, W. N. 2012. Catalog of Fishes. California Academy of Sciences Avaliable from: http://research.calacademy.org/ research/ichthyology/catalog/fishcatmain.asp (11 Oct 2012).

Langeani, F., R. M. C. Castro, O. T. Oyakawa, O. A. Shibatta, C. S. Pavanelli \& L. Casatti. 2007. Diversidade da ictiofauna do Alto Rio Paraná: composição atual e perspectivas futuras. Biota Neotropica, 7: 1-17.

Martins, F. O., B. B. Calegari \& F. Langeani. 2013. Microlepidogaster arachas, a new species of hypoptopomatine catfish (Siluriformes: Loricariidae) from the upper rio Paraná basin, Brazil. Zootaxa, 3608: 379-388.

Martins, F. O. \& F. Langeani. 2011. Rhinolekos, a new genus with three new species of Hypoptopomatinae (Siluriformes: Loricariidae) from upper rio Paraná. Neotropical Ichthyology, 9: 65-78.

Martins, F. O. \& F. Langeani. 2012. Hisonotus piracanjuba, a new species of Hypoptopomatinae (Siluriformes: Loricariidae) from the rio Paranaíba, upper rio Paraná system, central Brazil. Ichthyological Exploration of Freshwaters, 23: 29-36.

Montoya-Burgos, J. I. 2003. Historical biogeography of the catfish genus Hypostomus (Siluriformes: Loricariidae), with implications on the diversification of Neotropical ichthyofauna. Molecular Ecology 12, 1855-1867.

Nascimento, M. A. S. 1992. Geomorfologia do Estado de Goiás. Boletim Goiano de Geografia, 12: 1-22.

Nogueira, C., P. A. Buckup, N. A. Menezes, O. T. Oyakawa, T. P. Kasecker, M. B. Ramos Neto \& J. M. C. da Silva. 2010. Restricted-range fishes and the conservation of Brazilian freshwaters. Plos One, 5: 1-10.

Oyakawa, O. T., A. Akama \& A. M. Zanata. 2005. Review of the genus Hypostomus Lacépède, 1803 from the rio Ribeira de Iguape basin, with description of a new species (Pisces, Siluriforms, Loricariidae). Zootaxa, 921: 1-27.

Schaefer, S. A. 1997. The Neotropical cascudinhos: systematics and biogeography of the Otocinclus catfishes (Siluriformes: Loricariidae). Proceedings of the Academy of Natural Sciences of Philadelphia: 148: 1-120.

Taylor, W. R. \& G. C. Van Dike. 1985. Revised procedures for staining and clearing small fishes and other vertebrates for bone and cartilage study. Cybium, 9: 107-119.

Weber, C. 1985. Hypostomus dlouhyi, nouvelle espèce de Poissonchat cuirassè du Paraguay (Pisces, Siluriformes, Loricariidae). Revue suisse de Zoologie, 92: 955-968.

Zawadzki, C. H., C. S. Pavanelli \& F. Langeani. 2008a. Neoplecostomus (Teleostei: Loricariidae) from the upper Rio Paraná basin, Brazil, with description of three new species. Zootaxa, 1757: 31-48.

Zawadzki, C. H., L. F. C. Tencatt, L. F. C. \& O. Froehlich. 2014. A new unicuspid-toothed species of Hypostomus Lacépède, 1803 (Siluriformes: Loricariidae) from the rio Paraguai basin. Neotropical Ichthyology, 12: 97-104.

Zawadzki, C. H., C. Weber \& C. S. Pavanelli. 2008b. Two new species of Hypostomus Lacépède (Teleostei: Loricariidae) from the upper rio Paraná basin, Central Brazil. Neotropical Ichthyology, 6: 403-412. 